\title{
INITIAL GROWTH AND NUTRIENT ACCUMULATION IN PITAYA PLANTS AT DIFFERENT PHENOLOGICAL STAGES ${ }^{1}$
}

\author{
DENISE DE CASTRO LIMA ${ }^{2 *}$, NOUGLAS VELOSO BARBOSA MENDES ${ }^{3}$, MARIA FGÊNIA SALDANHA \\ DIÓGENES ${ }^{4}$, MÁRCIO CLEBER DE MEDEIROS CORRÊA ${ }^{3}$, WILLIAM NATALE ${ }^{3}$, \\ CARLOS ALBERTO KENJI TANIGUCHI ${ }^{5}$
}

\begin{abstract}
Information on nutritional management of pitaya crops are scarce. However, understanding the growth and nutrient accumulation in these plants at different developmental stages can assist in the development of rational soil fertilizer application programs for pitaya crops and decrease production costs. Thus, the objective of this work was to evaluate the growth and nutrient accumulation in pitaya plants throughout the crop cycle. Cladodes of pitaya plants of the Hylocereus setaceus species were grown in polyethylene pots containing a Typic Hapludult (Argissolo Vermelho-Amarelo Eutrófico) under full sun. The treatments consisted of six sampling times: 0, 60, 120, 180, 240, 300, and 360 days after planting (DAP). A randomized block experimental design with four replications was used. Four plants were sampled and evaluated for growth and nutrient accumulation at each sampling time. The pitaya plants presented an exponential growth up to 360 DAP and high nutrient absorption between 300 and 360 DAP. The nutrient and $\mathrm{Na}$ accumulations in the cladodes, in decreasing order, were: $3.91(\mathrm{~K}), 2.56(\mathrm{Ca}), 1.95(\mathrm{~N}), 1.24(\mathrm{P}), 0.45(\mathrm{Mg})$, $0.30(\mathrm{~S})$, and $0.06(\mathrm{Na}) \mathrm{g} \mathrm{plant}^{-1}$, and $14.86(\mathrm{Zn}), 12.72(\mathrm{Fe}), 12.37(\mathrm{Mn}), 5.37(\mathrm{~B})$, and $1.04(\mathrm{Cu}) \mathrm{mg} \mathrm{plant}^{-1}$. The highest relative growth rate and relative nutrient absorption rate were found between 60 and 120 DAP.
\end{abstract}

Keywords: Hylocereus setaceus. Cactaceae. Mineral nutrition. Nutritional requirement.

\section{CRESCIMENTO INICIAL E ACÚMULO DE NUTRIENTES EM PLANTAS DE PITAIA EM DIFERENTES PERÍODOS FENOLÓGICOS}

\begin{abstract}
RESUMO - A pitaia é uma cultura carente em informações a respeito do manejo nutricional. O conhecimento sobre o crescimento e o acúmulo de nutrientes nas diferentes fases de desenvolvimento da planta auxiliará na elaboração de programas de adubação racionais para a cultura, diminuindo os custos de produção. Objetivou-se com este trabalho avaliar o crescimento e o acúmulo de nutrientes na pitaia saborosa ao longo do tempo de cultivo. Cladódios de pitaia da espécie Hylocereus setaceus foram cultivados em vasos de polietileno, contendo um Argissolo Vermelho-Amarelo Eutrófico e conduzidas a céu aberto. Os tratamentos constituíram-se de seis épocas de amostragens: 0, 60, 120, 180, 240, 300 e 360 dias após o plantio e o delineamento experimental utilizado foi em blocos casualizados, com quatro repetições. Em cada época foram amostradas quatro plantas para avaliar o crescimento e o acúmulo de nutrientes. A pitaia saborosa apresentou crescimento exponencial até 360 dias após o plantio. Observou-se alta absorção de nutrientes no período de 300 a 360 dias após o plantio. O acúmulo de nutrientes nos cladódios, em ordem decrescente, foi: $3.91(\mathrm{~K}), 2.56(\mathrm{Ca}), 1.95(\mathrm{~N}), 1.24(\mathrm{P}), 0.45$ $(\mathrm{Mg}), 0.30(\mathrm{~S})$ e $0.06(\mathrm{Na}) \mathrm{g}_{\text {planta }^{-1}}$, e $14.86(\mathrm{Zn}), 12.72(\mathrm{Fe}), 12.37(\mathrm{Mn}), 5.37(\mathrm{~B})$ e1.04 (Cu) mg plant ${ }^{-1}$. A TCR e a TARN apresentaram maiores valores entre 60 e 120 dias.
\end{abstract}

Palavras-chave: Hylocereus setaceus. Cactaceae. Nutrição mineral. Exigência nutricional.

\footnotetext{
${ }^{*}$ Corresponding author

${ }^{1}$ Received for publication in $04 / 20 / 2020$; accepted in $01 / 26 / 2021$.

Paper extracted from the thesis of the first author.

${ }^{2}$ Soil Science Department, Universidade Federal do Ceará, Fortaleza, CE, Brazil; dennisedecastro@gmail.com - ORCID: 0000-0001-53137586.

${ }^{3}$ Plant Science Department, Universidade Federal do Ceará, Fortaleza, CE, Brazil; nouglasmendes@hotmail.com - ORCID: 0000-00034873-3206,mcleber@ufc.br - ORCID: 0000-0002-0702-4959, natale@ufc.br - ORCID: 0000-0001-9572-4463.

${ }^{4}$ Plant Science Department, Federal, Universidade Federal Rural do Semi-Árido, Mossoró, RN, Brazil; mariafgenia@hotmail.com ORCID: 0000-0002-7692-5240.

${ }^{5}$ Brazilian Agricultural Research Corporation, Embrapa Agroindústria Tropical, Fortaleza, CE, Brazil; carlos.taniguchi@embrapa.br ORCID: 0000-0002-1280-8678.
} 


\section{INTRODUCTION}

Hylocereus setaceus (pitaya) is a fruit species of the Cactaceae family that is raising the interest of fruit growers by presenting high commercial value (MOREIRA et al., 2011); it has a high potential as an ornamental and fruit plant and is an excellent source of vitamins. However, one of problems that affect pitaya crops is the lack of information about the nutritional management of the plants (COSTA et al., 2015). Little information is found on the quantity of nutrients required for pitaya plants over the crop cycle to obtain satisfactory results regarding their growth, development, and production.

Some studies on pitaya crops have shown how nutrients can affect their growth and production. Fernandes et al. (2018), evaluated the production and quality of pitaya fruits grown on soils with potassium fertilizer applications and found that the application of 106 to $133 \mathrm{~g}$ of $\mathrm{K}_{2} \mathrm{O}$ per plant in the first growth year and $200 \mathrm{~g}$ of $\mathrm{K}_{2} \mathrm{O}$ in the second and third year increases the production and quality of white-fleshed (Hylocereus undatus) and red-fleshed (Hylocereus polyrhizus) pitaya fruits. In addition, the use 150 to $225 \mathrm{mg} \mathrm{dm}^{-3}$ of P, 4 to $6 \mathrm{mg} \mathrm{dm}^{-3}$ of $\mathrm{Zn}$ (CORRÊA et al., 2014), 300 to $450 \mathrm{mg} \mathrm{dm}^{-3}$ of $\mathrm{N}$, and 150 to $225 \mathrm{mg} \mathrm{dm}^{-3}$ of K (ALMEIDA et al., 2014) results in a better growth of white-fleshed pitaya (H. undatus) seedlings.

However, the growth of pitaya still requires studies to determine the quantities of nutrients required throughout the crop cycle and define the times these nutrients are more required. This information would contribute to the development of rational soil fertilizer application programs for these crops. Soil fertilizer applications for pitaya crops in Brazil are done based on the experience of producers, or using rates that are recommended for other countries, which present ecological systems different from those of the Brazilian producing regions (CAVALCANTE et al., 2011), causing nutritional imbalances.

In this context, the objective of this work was to evaluate the growth and nutritional demand of pitaya $(H$. setaceus) plants and determine the times of the highest accumulations of different nutrients, relative growth rate, and relative nutrient absorption rate.

\section{MATERIAL AND METHODS}

The experiment was conducted at the Agriculture Sector of the Department of Plant Production Science of the Federal University of Ceará, in Fortaleza, state of Ceará, Brazil, from July 2016 to July 2017. The climatological data collected during the experimental period are presented in Figure 1.

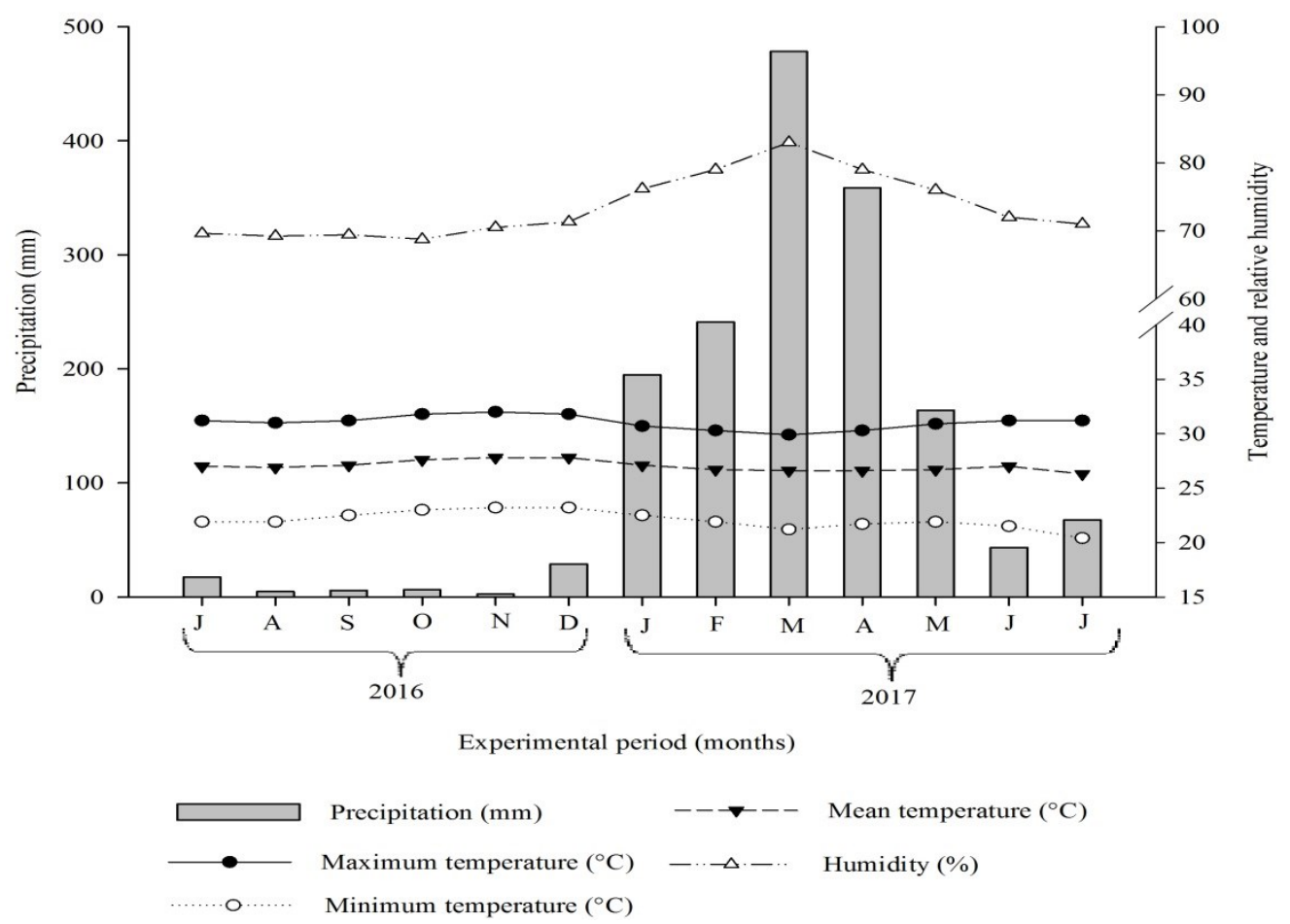

Figure 1. Climatological data, rainfall $(\mathrm{mm})$, maximum, mean, and minimum air temperatures $\left({ }^{\circ} \mathrm{C}\right)$, and relative air humidity (\%) in the experimental period. 
Pitaya seedlings were produced using cladodes with mean length of $25 \mathrm{~cm}$ (PONTES FILHO et al., 2014). The cladodes were planted at a depth of $3 \mathrm{~cm}$ in $3 \mathrm{dm}^{3}$ polyethylene bags containing sand soil + coconut fiber at the proportion of $1: 1 \mathrm{~V} \mathrm{v}^{-1}$. They remained for 60 days in a protected environment, until the rooting, and subsequently transplanted to $25 \mathrm{dm}^{3}$ polyethylene pots.

The soil used to fill the pots was classified as a Typic Hapludult (Argissolo Vermelho-Amarelo Eutrófico), and analyzed for chemical characteristics according to procedures described in Embrapa (2009) (Table 1).

Table 1. Initial chemical attributes of the soil used to fill the experimental pots.

\begin{tabular}{ccc}
\hline Soil chemical attributes & Unit & Values \\
\hline $\mathrm{P}$ & $\mathrm{mg} \mathrm{dm}^{-3}$ & 4.0 \\
Organic matter & $\mathrm{g} \mathrm{kg}^{-1}$ & 13.9 \\
$\mathrm{pH}$ in water & & 5.5 \\
$\mathrm{~K}^{+}$ & $\mathrm{mmol}_{\mathrm{c} \mathrm{dm}^{-3}}$ & 2.1 \\
$\mathrm{Ca}^{2+}$ & $\mathrm{mmol}_{\mathrm{c} \mathrm{dm}^{-3}}$ & 8.4 \\
$\mathrm{Mg}^{2+}$ & $\mathrm{mmol}_{\mathrm{c}} \mathrm{dm}^{-3}$ & 5.2 \\
$\mathrm{Na}^{+}$ & $\mathrm{mmol}_{\mathrm{c} \mathrm{dm}^{-3}}$ & 2.0 \\
$\mathrm{H}+\mathrm{Al}$ & $\mathrm{mmol}_{\mathrm{c} \mathrm{dm}^{-3}}$ & 17.3 \\
$\mathrm{Al}^{3+}$ & $\mathrm{mmol}_{\mathrm{c} \mathrm{dm}^{-3}}$ & 1.5 \\
$\mathrm{SB}$ & $\mathrm{mmol}_{\mathrm{c} \mathrm{dm}^{-3}}$ & 17.8 \\
$\mathrm{~T}$ & $\mathrm{mmol}_{\mathrm{c} \mathrm{dm}^{-3}}$ & 35.1 \\
$\mathrm{~V}$ & $\operatorname{\% o}^{-3}$ & 51.0 \\
$\mathrm{Cu}$ & $\mathrm{mg} \mathrm{dm}^{-3}$ & 0.2 \\
$\mathrm{Fe}$ & $\mathrm{mg} \mathrm{dm}^{-3}$ & 40.0 \\
$\mathrm{Zn}$ & $\mathrm{mg} \mathrm{dm}^{-3}$ & 0.1 \\
$\mathrm{Mn}$ & $\mathrm{mg} \mathrm{dm}^{-3}$ & 3.6 \\
$\mathrm{~B}$ & $\mathrm{mg} \mathrm{dm}^{-3}$ & 0.3 \\
\hline
\end{tabular}

$\mathrm{OM}=$ organic matter; $\mathrm{pH}$ in water; $\mathrm{P}, \mathrm{Na}$ and $\mathrm{K}$, Mehlich-1 extractor; $\mathrm{Ca}, \mathrm{Mg}$ and $\mathrm{Al}, \mathrm{KCl}$ extractor; $\mathrm{H}+\mathrm{Al}$, calcium acetate extractor; $\mathrm{SB}=$ sum of exchangeable bases; $\mathrm{T}=$ cation exchange capacity at $\mathrm{pH} 7.0 ; \mathrm{V}=$ base saturation; $\mathrm{Cu}, \mathrm{Zn}, \mathrm{Mn}$ and $\mathrm{Fe}$, DTPA extractor; $\mathrm{B}, \mathrm{HCl}$ extractor.

The soil $\mathrm{pH}$ was corrected based on the soil analysis, using agricultural limestone (total neutralizing power of $91 \%$ ) to raise the base saturation to $70 \% ; 9.1 \mathrm{~g}$ of limestone was applied per pot (25 kg of soil). The seedlings were transplanted to the pots after 30 days of soil incubation and grown under full sun.

The seedlings were transplanted to the pots with only the main cladode (primary cladode), and grown with a single stem up to $1.5 \mathrm{~m}$ height, when they were pruned to induce the primary lateral cladode emission (one cladode for each side). These cladodes were pruned when they reached $40 \mathrm{~cm}$ to stimulate the emission of secondary lateral cladodes (three cladodes for each side). Pitaya is a Cactaceae species that requires a stem conduction system; thus, a trellis system was used.

Soil fertilizers were applied using the nutrient rates recommended by Almeida et al. (2014) and Corrêa et al. (2014) for pitaya crops, which were 750 $(\mathrm{N}), 375(\mathrm{P}), 375(\mathrm{~K})$ and $10(\mathrm{Zn}) \mathrm{mg} \mathrm{dm}^{-3}$. The nutrient source used were urea $(46 \% \mathrm{~N})$, simple superphosphate $\left(18 \% \mathrm{P}_{2} \mathrm{O}_{5}, 25 \% \mathrm{CaO}\right.$ and $\left.12 \% \mathrm{~S}\right)$, potassium chloride $\left(62 \% \mathrm{~K}_{2} \mathrm{O}\right)$ and FTE BR-12 (a granulated mixture of micronutrients containing $9 \%$ $\mathrm{Zn}, 1.80 \% \mathrm{~B}, 0.80 \% \mathrm{Cu}, 2 \% \mathrm{Mn}$, and $0.10 \% \mathrm{Mo}$ ).
The rates were adjusted to the soil volume used $\left(25 \mathrm{dm}^{3}\right)$. Therefore, the rates applied to each pot were $120 \mathrm{~g}$ of simple superphosphate, $2.8 \mathrm{~g}$ of FTEBR-12, $40.7 \mathrm{~g}$ of urea, and $18.2 \mathrm{~g}$ of potassium chloride.

A randomized block experimental design with four replications was used; the treatments consisted of sampling times $(0,60,120,180,240,300$, and 360 days after planting).

The planting soil fertilizer application was equal for all pots; the simple superphosphate and $50 \%$ of the FTE BR-12 rate were applied when the seedlings were transplanted to the pots. The other $50 \%$ of the FTE BR-12 rate was applied at 180 days after the transplant to the pots. The urea and potassium chloride were split in eleven equal rates of $3.70 \mathrm{~g}$ and $1.65 \mathrm{~g}$, respectively, and applied monthly after solubilization in water to favor incorporation to the soil. Urea and potassium chloride applications tend to minimize the nutrient losses by leaching. The plants were manually irrigated three times a week, applying $1 \mathrm{~L}$ of water per pot; the irrigation was suspended at the beginning of the rainy season.

The characteristics evaluated at each sampling time were: a) sum of the lengths of all cladodes emitted, except the main cladode, whose 
results were expressed in $\mathrm{cm} \mathrm{plant}^{-1}$; b) shoot dry matter: all cladodes were placed in paper bags and placed in a forced air-circulation oven at $65^{\circ} \mathrm{C}$ until constant weight; the results were expressed in g plant $^{-1}$; c) shoot macro and micronutrient $(\mathrm{N}, \mathrm{P}, \mathrm{K}$, $\mathrm{Ca}, \mathrm{Mg}, \mathrm{S}, \mathrm{Cu}, \mathrm{Fe}, \mathrm{Zn}, \mathrm{Mn}$, and B) accumulation and $\mathrm{Na}$ contents: determined according to the methodology described in Embrapa (2009), macronutrient (g plant ${ }^{-1}$ ) and micronutrient (mg plant ${ }^{-1}$ ) accumulations were determined by multiplying the contents of each nutrient in the shoot by the shoot dry matter weight.

The data obtained were subjected to analysis of variance and the means fitted to an exponential model, represented by Equation 1:

$$
Y=e^{a-b X}
$$

The relative growth rate (RGR) (Equation 2) and relative nutrient absorption rate (RNAR) (Equation 3) were determined according to the equations of Welbank (1962):

$$
\mathrm{RGR}=\frac{\left(\ln \mathrm{M}_{2}-\ln \mathrm{M}_{1}\right)}{\left(\mathrm{t}_{2}-\mathrm{t}_{1}\right)}
$$

where RGR is the relative growth rate in $\mathrm{g} \mathrm{g}^{-1}$

\section{(A)}

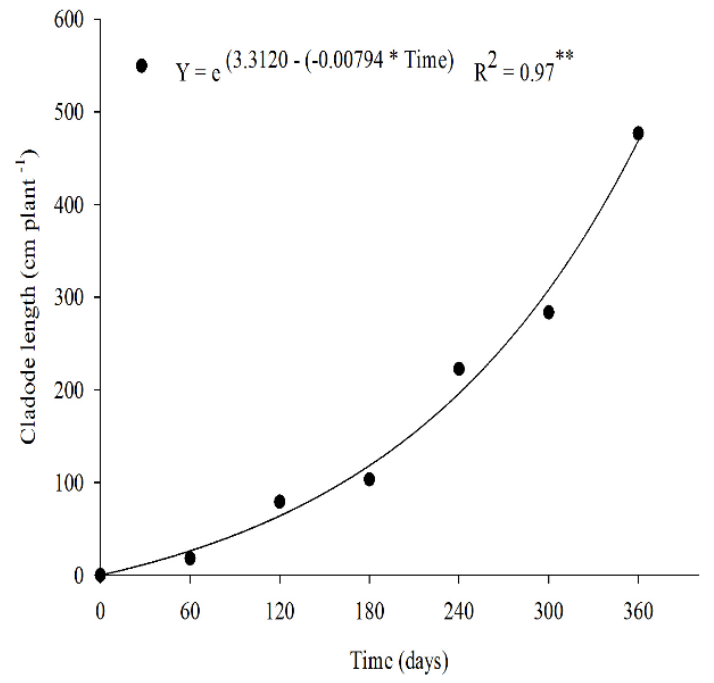

day $^{-1} ; \ln$ is the Neperian logarithm; $\mathrm{M}_{1}$ and $\mathrm{M}_{2}$ are the dry matter weights of the plant or plant organ in $g$ per plant at times $t_{1}$ and $t_{2}$, respectively; and $t_{1}$ and $\mathrm{t}_{2}$ are the period, in days, between evaluations.

$$
\operatorname{RNAR}=\frac{\left(\mathrm{N}_{2}-\mathrm{N}_{1}\right)\left(\ln \mathrm{M}_{2}-\ln \mathrm{M}_{1}\right)}{\left(\mathrm{t}_{2}-\mathrm{t}_{1}\right)\left(\mathrm{M}_{2}-\mathrm{M}_{1}\right)}
$$

where RNAR is the relative nutrient absorption rate in $\mathrm{mg} \mathrm{g}^{-1}$ day $^{-1}$ or $\mu \mathrm{g} \mathrm{g}^{-1}$ day $^{-1} ; \mathrm{N}_{1}$ and $\mathrm{N}_{2}$ are the nutrient quantities in the plant organ at times $t_{1}$ and $t_{2}$, respectively; $\ln$ is the Neperian logarithm; $M_{1}$ and $M_{2}$ are the total plant dry matter weights at times $t_{1}$ and $t_{2}$, respectively; and $t_{1}$ and $t_{2}$ are the period between evaluations.

The SAS program (SAS, 2012) was used for the statistical analysis.

\section{RESULTS AND DISCUSSION}

The initial growth of the pitaya plants was characterized by a small increase in cladode length up to 180 days after planting (DAP), with daily rates of $0.64 \mathrm{~cm} \mathrm{plant}^{-1}$ (Figure 2A). A more vigorous cladode growth was found from 180 to 360 DAP, with a daily growth rate of $2.02 \mathrm{~cm}$ plant $^{-1}$.

(B)

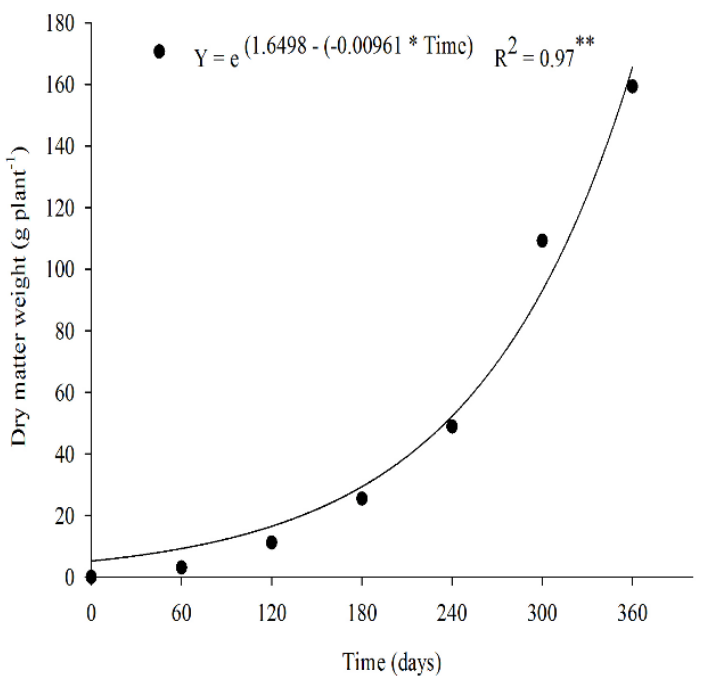

Figure 2. Cladode length (A) and dry matter weight (B) of pitaya (Hylocereus setaceus) as a function of sampling times.

The mean pitaya cladode length at 360 DAP was $478.377 \mathrm{~cm}$ plant $^{-1}$; this result is higher than that obtained by Cajazeira (2016), who found a mean pitaya cladode length of $84.9 \mathrm{~cm}$ at 270 DAP. This difference in cladode length may be related to the adequate supply of nutrients, such as the nitrogen, which can affect the growth of these plant structures. Nitrogen affects the cell division and stretching, promoting the cladode length (CUNHA et al., 2012).

The shoot dry matter accumulation presented 
small increases up to 180 DAP, with a daily increase rate of $0.163 \mathrm{~g} \mathrm{day}^{-1}$, and an increase of $0.756 \mathrm{~g} \mathrm{day}^{-1}$ from 180 to 360 DAP (Figure 2B). The total accumulated dry matter weight in the plants was only $18 \%$ up to $180 \mathrm{DAP}$, the remaining $82 \%$ were accumulated in the following stage, up to 360 DAP. This small initial increase rate may be attributed to the low size and number of cladodes in the plants during this period; The $\mathrm{CO}_{2}$ absorption and photoassimilate production were probably low at this stage, resulting in lower dry matter accumulation. Phosphorus is an important nutrient for photosynthesis and beginning of root growth; it improves water use efficiency and absorption and use of other nutrients (MALAVOLTA, 2006), including potassium. Potassium increases the pitaya cladode diameter (CAJAZEIRA et al., 2018) and is related to stomatal opening and closure processes, and carbohydrate translocations (MARSCHNER,

2012). According to Laredo (2016), the size and number of buds are important characteristics for pitaya plants; plants that present higher shoot vigor can better capture light and produce photoassimilates, improving the plant nutrition and accumulation of reserves.

The periods of higher cladodes growth and dry matter accumulation (Figures $2 \mathrm{~A}$ and $\mathrm{B}$ ) were those of higher nutrient demand (Figure 3 ). The pitaya nutrient absorption follows, in general, the standard of the growth curve or dry matter accumulation at this initial growth stage, presenting two different stages: the first with slow absorption, and the second with intense nutrient absorption.

The accumulation of nutrients and $\mathrm{Na}$ by the pitaya cladodes at the end of experimental period presented the following decreasing order: $\mathrm{K}>\mathrm{Ca}>$ $\mathrm{N}>\mathrm{P}>\mathrm{Mg}>\mathrm{S}>\mathrm{Na}>\mathrm{Zn}>\mathrm{Fe}>\mathrm{Mn}>\mathrm{B}>\mathrm{Cu}$.

(B)
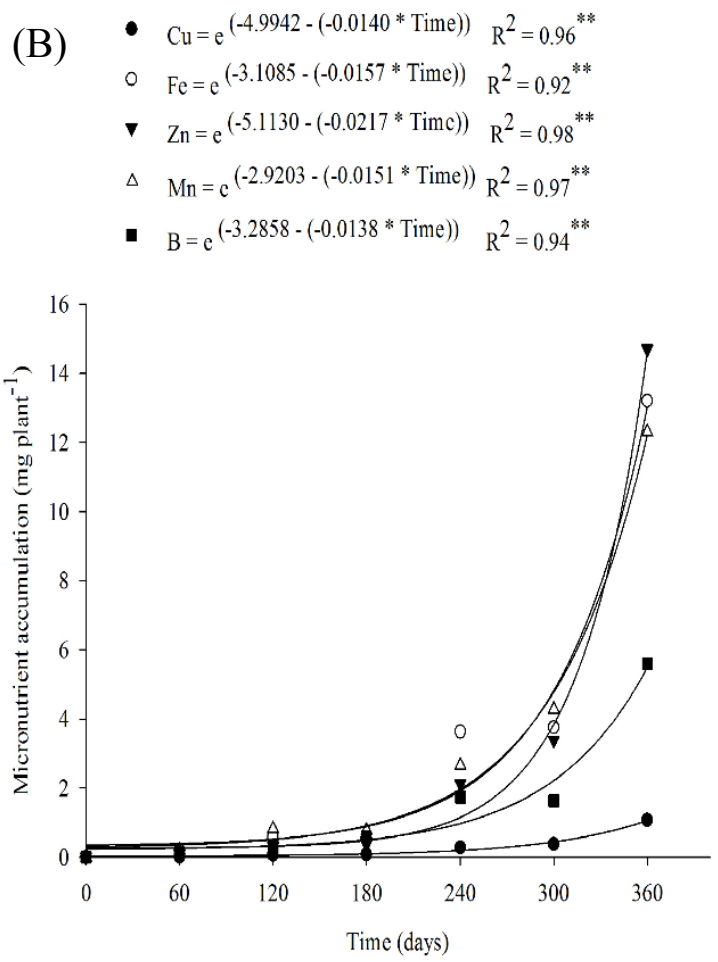

Figure 3. Macronutrient accumulation and $\mathrm{Na}$ contents (A) and micronutrient accumulation (B) in pitaya cladodes as a function of sampling times.

$\mathrm{K}, \mathrm{Ca}$, and $\mathrm{N}$ were the most accumulated macronutrients by the cladodes, all presenting maximum accumulation rate from 300 to 360 DAP. The maximum accumulation of these nutrients occurred in the period of intense plant growth (Figure $3 \mathrm{~A}$ ). The maximum accumulation rates of $\mathrm{K}$, $\mathrm{Ca}$, and $\mathrm{N}$ were 0.028, 0.024, and $0.013 \mathrm{~g} \mathrm{plant}^{-1} \mathrm{day}^{-1}$, respectively. The maximum accumulations of $\mathrm{K}, \mathrm{Ca}$, and $\mathrm{N}$ at the end of 360 DAP were 3.91, 2.56, and $1.95 \mathrm{~g}$ plant $^{-1}$, respectively.

$\mathrm{K}$ was the most demanded macronutrient by the pitaya plants, which makes the supply of this nutrient essential during the whole pitaya crop cycle. Despite $\mathrm{K}$ is not part of the structure of any organic compound, it is important to plants by affecting the stomatal opening and closure, translocation of sugars, photosynthesis, and osmotic regulation (MALAVOLTA, 2006). Studies on the effect of K on the development of pitaya plants indicate 
increases in cladode length, diameter, and thickness (CAJAZEIRA et al., 2018), and improvements in fruit quality (FERNANDES et al., 2018).

$\mathrm{Ca}$ accumulation was slow up to $180 \mathrm{DAP}$, with $0.199 \mathrm{~g} \mathrm{plant}^{-1}$ in the pitaya cladodes; higher $\mathrm{Ca}$ accumulation in the plants were found after 240 DAP. The gradually increases in $\mathrm{Ca}$ in the cladodes up to 360 DAP may be related to the low mobility of $\mathrm{Ca}$ in the phloem, which prevents the redistribution of this element from the cladodes to other plant organs (MALAVOLTA, 2006); probably, the older the cladode, the higher the $\mathrm{Ca}$ accumulation. Lima et al. (2019) evaluated the growth and nutrient accumulation in red-fleshed pitaya shoots and found that $\mathrm{Ca}$ contents tend to increase as the plants age.

$\mathrm{N}$ was the third most accumulated macronutrient by the pitaya plants, presenting a maximum accumulation rate of $1.95 \mathrm{~g} \mathrm{plant}^{-1}$ at 360 DAP. According to Luders and Mc Mahon (2006), nitrogen is required by pitaya during the whole vegetative growth stage, and is responsible for the emission of new cladode buds. Almeida et al. (2014) found that increases in $\mathrm{N}$ accumulation in pitaya (Hylocereus undatus) cladodes is induced by increasing $\mathrm{N}$ application rates.

$\mathrm{P}$ was the fourth most accumulated nutrient by the pitaya plants, with maximum accumulation rate of $0.011 \mathrm{~g} \mathrm{plant}^{-1}$ day $^{-1}$ form 300 and 360 DAP. Each plant had accumulated $1.24 \mathrm{~g}$ of $\mathrm{P}$ in the cladodes at the end of the experimental period. This result differs from those of Moreira et al. (2016), who found lower $\mathrm{P}$ accumulation in shoots of whitefleshed plants $\left(0.16 \mathrm{~g} \mathrm{plant} \mathrm{t}^{-1}\right)$. These differences were probably due to morphological and physiological aspects of the species, and the quantity of available $\mathrm{P}$ to the plants in the soil, since higher $\mathrm{P}$ rates were applied in the present study.

$\mathrm{Mg}$ and $\mathrm{S}$ were the least required macronutrients by the pitaya plants, with maximum accumulations of $0.45 \mathrm{~g} \mathrm{plant}^{-1}$ and $0.30 \mathrm{~g} \mathrm{plant}^{-1}$, respectively, at 360 DAP. High $\mathrm{K}$ and $\mathrm{Ca}$ concentrations may inhibit $\mathrm{Mg}$ absorption, since $\mathrm{K}$, $\mathrm{Ca}$, and $\mathrm{Mg}$ compete for same absorption sites in the roots; thus, the cation with higher concentration in the soil solution is preferentially absorbed in detriment of the others (BRADY; WEIL, 2013). The $\mathrm{S}$ requirement for a good plant growth varies, in general, from $0.1 \%$ to $0.5 \%$ of the plant dry weight (MARSCHNER, 2012); thus, the total S accumulation found in the pitaya shoots is within this range.

$\mathrm{Na}$ accumulation reached $0.064 \mathrm{~g} \mathrm{plant}^{-1}$ at 360 DAP, with a maximum accumulation rate of $0.028 \mathrm{~g} \mathrm{plant}^{-1}$ from 300 to $360 \mathrm{DAP}$. According to Taiz et al. (2017), species that use C4 and CAM routes for carbon fixation require sodium ions, since these ions stimulate the growth upon the cell expansion. $\mathrm{Na}$ is absorbed by plants in the ionic form $\left(\mathrm{Na}^{+}\right)$, which has high mobility in plant tissues; $\mathrm{Na}$ concentrations in the shoot dry matter vary from 0.013 to $35.1 \mathrm{~g} \mathrm{~kg}^{-1}$ (INOCÊNCIO; CARVALHO; FURTINI NETO, 2014).

Regarding the micronutrients, $\mathrm{Zn}, \mathrm{Fe}$, and $\mathrm{Mn}$ were the most accumulated by the pitaya shoots. $\mathrm{Zn}$ accumulation in the pitaya shoots was $14.86 \mathrm{mg} \mathrm{plant}^{-1}$ at $360 \mathrm{DAP}$; the highest demand was found from 300 to 360 DAP, with accumulation of $10.82 \mathrm{mg}$ plant $^{-1}$ in this period, corresponding to $72.81 \%$ of the total zinc in the shoot. The maximum $\mathrm{Zn}$ accumulation rate from 300 and 360 DAP was $0.18 \mathrm{mg} \mathrm{plant}^{-1}$ day $^{-1}$. Corrêa et al. (2014) evaluated the initial growth of pitaya plants as a function of combination of phosphorus and zinc rates and found high $\mathrm{Zn}$ accumulation in the cladodes under good $\mathrm{Zn}$ availability conditions in the substrate.

Fe demand increased from 240 DAP (Figure 3B) probably due to the functions of this element in the photosynthetic process, since the cladode production is intensified in this period, increasing the plant Fe demand. The shoots of the plants had accumulated $7.37 \mathrm{mg}$ of $\mathrm{Mn}$ at the end of the experimental period. According to Millaleo et al. (2010), high Mn accumulations in cladodes are probably related to the function of $\mathrm{Mn}$ in the plant; it is part of structures of photosynthetic proteins and enzymes and essential for photosynthesis. $\mathrm{B}$ and $\mathrm{Cu}$ were the least accumulated micronutrients by the pitaya shoots, with maximum accumulations of 5.37 and $1.04 \mathrm{mg} \mathrm{plant}^{-1}$, respectively, at $360 \mathrm{DAP}$.

The relative growth rate (RGR) represents the increase in dry matter weight per unit of weight in a period. The highest RGR of pitaya plants was found from 60 to 120 DAP $\left(0.022 \mathrm{~g} \mathrm{~g}^{-1}\right.$ day $\left.^{-1}\right)$, with a subsequent decrease up to 360 DAP (Table 2). According to Gonçalves et al. (2017), decreases in RGR over the crop cycle decrease the plants' capacity to produce newly parts over the cycle.

Table 2. Relative growth rate (RGR) of pitaya (Hylocereus setaceus) cladodes as a function of sampling times.

\begin{tabular}{cc}
\hline Period & $\begin{array}{c}\text { RGR } \\
\text { (whole pitaya plants) }\end{array}$ \\
\hline Days & $\mathrm{g} \mathrm{g}^{-1}$ day $^{-1}$ \\
\hline $0-60$ & 0.019 \\
$60-120$ & 0.022 \\
$120-180$ & 0.014 \\
$180-240$ & 0.011 \\
$240-300$ & 0.013 \\
$300-360$ & 0.006 \\
\hline
\end{tabular}


The RGR was used to calculate the relative nutrient absorption rate (RNAR) for all plants. RNAR depends on the plant weight and factors intrinsic to the plant metabolism, related to the plant's physiological needs for each nutrient (ROZANE et al., 2013). The RNAR varied as a function of the nutrient and sampling time. The highest RNAR in the pitaya plants was found, in general, between 60 and 120 DAP (Table 3). Rozane et al. (2013) found that higher RNAR are found in the initial evaluation periods due to the small dry matter accumulations at this stage, which is denoted by the higher nutrient contents in the quotient of the equation and, therefore, a higher RNAR.

Table 3. Relative nutrient absorption rate (RNAR) of pitaya cladodes as a function of sampling times.

\begin{tabular}{|c|c|c|c|c|c|c|}
\hline \multirow{2}{*}{$\begin{array}{c}\text { RNAR } \\
\text { (whole pitaya plants) } \\
\text { Nutrients }\end{array}$} & \multicolumn{6}{|c|}{ Periods (days after planting) } \\
\hline & $0-60$ & $60-120$ & $120-180$ & $180-240$ & $240-300$ & $300-360$ \\
\hline $\mathrm{N}\left(\mathrm{mg} \mathrm{g}^{-1} \mathrm{dia}^{-1}\right)$ & 0.49 & 0.48 & 0.14 & 0.19 & 0.02 & 0.14 \\
\hline $\mathrm{P}\left(\mathrm{mg} \mathrm{g}^{-1} \mathrm{dia}^{-1}\right)$ & 0.06 & 0.16 & 0.02 & 0.12 & 0.02 & 0.10 \\
\hline $\mathrm{K}\left(\mathrm{mg} \mathrm{g}^{-1} \mathrm{dia}^{-1}\right)$ & 0.79 & 1.20 & 0.01 & 0.49 & 0.05 & 0.27 \\
\hline $\mathrm{Ca}\left(\mathrm{mg} \mathrm{g}^{-1} \mathrm{dia}^{-1}\right)$ & 0.13 & 0.21 & 0.03 & 0.25 & 0.06 & 0.20 \\
\hline $\operatorname{Mg}\left(\mathrm{mg} \mathrm{g}^{-1} \mathrm{dia}^{-1}\right)$ & 0.06 & 0.21 & 0.00 & 0.07 & 0.00 & 0.04 \\
\hline $\mathrm{S}\left(\mathrm{mg} \mathrm{g}^{-1} \mathrm{dia}^{-1}\right)$ & 0.06 & 0.03 & 0.01 & 0.04 & 0.00 & 0.02 \\
\hline $\mathrm{Na}\left(\mathrm{mg} \mathrm{g}^{-1} \mathrm{dia}^{-1}\right)$ & 0.06 & 0.00 & 0.00 & 0.00 & 0.00 & 0.01 \\
\hline $\mathrm{Cu}\left(\mu \mathrm{g} \mathrm{g}^{-1} \mathrm{dia}^{-1}\right)$ & 0.06 & 0.16 & 0.00 & 0.09 & 0.02 & 0.09 \\
\hline $\mathrm{Fe}\left(\mu \mathrm{g} \mathrm{g}^{-1} \mathrm{dia}^{-1}\right)$ & 1.22 & 1.01 & 0.00 & 1.44 & 0.03 & 1.19 \\
\hline $\mathrm{Zn}\left(\mu \mathrm{g} \mathrm{g}^{-1} \mathrm{dia}^{-1}\right)$ & 0.49 & 0.61 & 0.06 & 0.81 & 0.28 & 1.42 \\
\hline $\operatorname{Mn}\left(\mu \mathrm{g} \mathrm{g}^{-1} \mathrm{dia}^{-1}\right)$ & 1.16 & 1.65 & 0.00 & 0.87 & 0.36 & 1.01 \\
\hline $\mathrm{B}\left(\mu \mathrm{g} \mathrm{g}^{-1} \mathrm{dia}^{-1}\right)$ & 0.79 & 0.45 & 0.28 & 0.53 & 0.00 & 0.50 \\
\hline
\end{tabular}

The RNAR determines the quantity of nutrient accumulated as a function of the plant weight; determining this nutritional index is important to produce seedlings of fruit trees that are propagated vegetatively by cutting, including pitaya, since the biomass of pitaya seedlings at the transplant time is enough to obtain the RNAR (PRADO; FRANCO, 2007). In addition, the nutrient mobility/redistribution in plants affects physiological processes; according to Malavolta (2006), N, P, and $\mathrm{Na}$ are highly mobile; $\mathrm{P}, \mathrm{Cl}, \mathrm{S}$, and $\mathrm{Mg}$ are mobile; $\mathrm{Zn}, \mathrm{Cu}, \mathrm{Fe}, \mathrm{Mn}$, and Mo are partially mobile; and $\mathrm{Ca}$ and $\mathrm{B}$ are not mobile in the plant. Moreover, the RNAR results are important for an adequate supply of nutrients in the first days after planting the seedlings, when the nutrient absorption is higher, to ensure an adequate development of the plants.

\section{CONCLUSIONS}

The pitaya (Hylocereus setaceus) plants presented an exponential growth up to 360 days after planting.

The highest nutrient accumulations were found from 300 and 360 days after planting.

The highest relative growth rate and relative nutrient absorption rate were found between 60 and 120 days after planting.

\section{ACKNOWLEDGEMENTS}

The authors thank the Funcap for granting a $\mathrm{PhD}$ scholarship to the first author; the Federal University of Ceará for providing the area for the implementation of the experiment; and the Brazilian Agricultural Research Corporation (Embrapa Agroindústria Tropical) for the support in the soil chemical analysis.

\section{REFERENCES}

ALMEIDA, E. I. B. et al. Nitrogênio e potássio no crescimento de mudas de pitaia. Revista Brasileira de Fruticultura, 36: 1015-1024, 2014.

BRADY, N. C.; WEIL, R. R. Elementos da natureza e propriedades dos solos. 3. ed. Porto Alegre, RS: Bookman, 2013. 716 p.

CAJAZEIRA, J. P. Crescimento e ecofisiologia de pitaias cultivadas em vasos submetidas a diferentes doses de K e Ca. 2016. 140 f. Tese (Doutorado em Agronomia: Área de Concentração em Fitotecnia) - Universidade Federal do Ceará, Fortaleza, 2016.

CAJAZEIRA, J. P. et al. Growth and gas exchange 
in white pitaya under different concentrations of potassium and calcium. Revista Ciência Agronômica, 49: 112-121, 2018.

CAVALCANTE, I. H. L. et al. Adubação orgânica e intensidade luminosa no crescimento e desenvolvimento inicial da Pitaya em Bom Jesus-PI. Revista Brasileira de Fruticultura, 33: 970-983, 2011.

CORRÊA, M. C. M. et al. Crescimento inicial de pitaia em função de combinações de doses de fósforo -zinco. Revista Brasileira de Fruticultura, 36: 261$270,2014$.

COSTA, A. C. et al. Adubação orgânica e Lithothamnium no cultivo da pitaia vermelha. Semina, 36: 77-87, 2015.

CUNHA, D. N. F. V. et al. Morfometria e acúmulo de biomassa em palma forrageira sob doses de nitrogênio. Revista Brasileira de Saúde e Produção Animal, 13: 1156-1165, 2012.

EMBRAPA - Empresa Brasileira de Pesquisa Agropecuária. Manual de análises químicas de solos, plantas e fertilizantes. 2. ed. Brasília, DF: Embrapa Informação Tecnológica, 2009. 627 p.

FERNANDES, D. R. et al. Improvement of production and fruit quality of pitayas with potassium fertilization. Acta Scientiarum Agronomy, 40: 2-9, 2018.

GONÇALVES, E. D. V. et al. Crescimento e produtividade de cultivares de alface em ambiente protegido com e sem tela termorrefletora. Scientia Agraria Paranaensis, 16: 193-199, 2017.

INOCÊNCIO, M. F.; CARVALHO, J. G.; FURTINI NETO, A. E. Potássio, sódio e crescimento inicial de espécies florestais sob substituição de potássio por sódio. Revista Árvore, 38: 113-123, 2014.

LAREDO, R. R. Épocas de coleta e tipos de incisão no cladódio para propagação de pitaia vermelha de polpa branca. 2016. $83 \mathrm{f}$. Tese (Doutorado em Agronomia: Área de Concentração em Produção Vegetal) - Universidade Federal de Lavras, Lavras, 2016.

LIMA, D. C. et al. Growth and nutrient accumulation in the aerial part of red Pitaya (Hylocereus sp.). Revista Brasileira de Fruticultura, 41: 1-11, 2019.

LUDERS, L.; Mc MAHON, G. The pitaya or dragon fruit (Hylocereus undatus). 2006. Disponível em: < https://dpir.nt.gov.au/ data/assets/ pdf file/0004/232933/778.pdf $>$. Acesso em: 30 jan. 2018 .

MALAVOLTA, E. Manual de nutrição mineral de plantas. 1. ed. Piracicaba, SP: Editora Agronômica Ceres, 2006. $631 \mathrm{p}$.

MARSCHNER, H. Mineral nutrition of higher plants, 3th. ed. London: Academic Press, 2012. 889 p.

MILLALEO, R. et al. Manganese as essential and toxic element for plants: transport, accumulation and resistance mechanisms. Journal of Soil Science and Plant Nutrition, 10: 476-494, 2010.

MOREIRA, R. A. et al. Nutrient accumulation at the initial growth of pitaya plants according to phosphorus fertilization. Pesquisa Agropecuária Tropical, 46: 230-237, 2016.

MOREIRA, R. A. et al. Crescimento de pitaiavermelha com adubação orgânica e granulado bioclástico. Ciência Rural, 41: 785-788, 2011.

PONTES FILHO, F. T. et al. Comprimento de estacas e concentrações de ácido indolbutírico (AIB) na propagação vegetativa de pitaia. Revista Ciência Agronômica, 45: 46-51, 2014.

PRADO, R. M; FRANCO, C. F. Eficiência de absorção de nutrientes em mudas de goiabeiras Paluma e Século XXI, cultivadas em solução nutritiva. Revista Brasileira de Ciências Agrária, 2: 275-280, 2007.

ROZANE, D. E. et al. Caracterização biométrica e acúmulo de nutrientes em porta-enxertos de caramboleira cultivada em solução nutritiva. Revista Ciência Agronômica, 44: 426-436, 2013.

SAS INSTITUTE INC. SAS/STAT: User's Guide. Versão 12.1. Cary: SAS Institue, 2012.

TAIZ, L. et al. Fisiologia e Desenvolvimento Vegetal. 6. ed. Porto Alegre, RS: Artmed, 2017. 888 p.

WELBANK, P. J. The effects of competition with Agropyron repens and of nitrogen and water supply on the nitrogen content of Impatiens parviflora. Annals of Botany, 26: 361-373, 1962. 